\title{
Arturo E. García Niño, Convertimos la lucha en patrimonio. Testimonios de don Manuel García Amador. Un dirigente seccional del movimiento ferrocarrilero de 1958-1959 en Veracruz, Xalapa, Veracruz, Universidad Veracruzana, 2014.
}

Arrumbada durante muchos años como la menor de presuntas hermanas mayores, la historia oral se rebeló en los primeros años del medio siglo XX en México para dejar de ser considerada un afluente informativo más en torno a los procesos sociales recientes y cercanos. De una fuente primaria subsidiaria de proyectos historiográficos mayores se reveló, por fuerza de sí misma, como una vertiente autónoma de aproximación contribuyente a la historiografía nacional y acerca de los hechos nacionales; y de manera relevante, sobre los hechos regionales y locales.

Valedera integralmente y par de cualquier otro paradigma interpretativo histórico/historiográfico, la práctica y teorización de la historia oral en nuestras patrias nacionales y gremiales, así como en nuestras matrias regionales y subgremiales, son hoy actuantes protagónicas en el teatro donde la memoria transita en su añeja lucha para vencer al olvido voluntario por razones ideológicas, o involuntario porque algunas ópticas atisban generalizadoras desde el altiplano mexicano y centran en tal espacio sus abordajes. Y esos olvidos colocan en la excentricidad los abordajes desde la(s) provincia(s) y sobre las prácticas sociales y simbólicas, que acaecidas en ésta(s) dimensionan y redimensiona los procesos nacionales. De estas cuestiones trata específicamente la obra que motiva las presentes líneas.

Si toda reconstrucción histórica se construye desde el presente para, y por, incidir en éste, la historia reciente se resiente más. Los hechos más cercanos en el tiempo y en el espacio sobredeterminan de manera más directa y revulsiva las historias locales y de vida cotidianas, ésas que en la corta duración modifican actuares, se integran a la reconstrucción de ejercicios identitarios permanentes y por ende trascienden en el tiempo, independientemente de ser parte vital de los protagonistas directos de los hechos. Y a ello se refiere Convertimos la lucha en patrimonio..., libro escrito por Arturo E. García Niño y resultante de una investigación sustentada en fuentes primarias y secundarias cuyo eje es la historia oral, mediante la cual el autor reconstruye la génesis del movimiento ferrocarrilero que en 1958-1959 realizó la hasta entonces huelga, con sus previos paros de labores, más importante de la postrevolución mexicana.

En palabras del autor la obra trata 
de un tema: el movimiento ferrocarrilero de 1958-1959... de una ciudad: Tierra Blanca, Veracruz... y de una persona: don Manuel García Amador, conductor de trenes en la División VCI Sureste y miembro de la sección 25 del Sindicato de Trabajadores Ferrocarrileros de la República Mexicana, que [da] su testimonio como participante del movimiento citado [y] habitante de dicha ciudad. (p. 12)

Es, entonces, el texto aquí comentado, un trabajo de historia oral desde el ámbito de lo local, recuperador del cómo se vivió en una de varias ciudades ferrocarrileras - "aquellas que fueron en su momento y por su actividad ejes de una vida regional concreta integradora de la vida nacional... [y] cuya vida económica central dependía de la actividad de los ferrocarriles" (p. 18)- el movimiento que inauguró el segundo medio siglo XX mexicano.

Historiador y escritor, Arturo E. García Niño es también pionero en el acercamiento desde la academia -y desde la historia oral para el caso- a la llegada y desarrollo inicial del son montuno a nuestro país;' a la narconarrativa y sus autores; ${ }^{2}$ al "cuarteto de la guerrilla”, de Carlos Montemayor ${ }^{3}$ entendido como un trabajo narrativo literario historiográfico; y a la historia del beisbol mexicano y la huelga de la Asociación Nacional de Beisbolistas mexicanos en 1980. ${ }^{4}$ Galardonado con mención honorífica en el Premio Nacional de Investigación Histórica José C. Valadés 2007, del INEHRM, García Niño justifica que realizó Convertimos la lucha en patrimonio... porque

el trabajo historiográfico que se ha desarrollado hasta nuestros días [sobre el movimiento ferrocarrilero] pone énfasis en la dinámica nacional... en las negociaciones, las situaciones y los conflictos que acaecieron en la ciudad de México... pero poco sabemos del cómo se vivieron los paros y huelgas, así como la represión del ejército, en las diversas ciudades ferrocarrileras de...provincia, donde la incidencia de los ferrocarriles era a tal grado importante que... el tiempo se iba estructurando según el silbato de los talleres anunciando la hora, así como por la entrada y salida de los diversos turnos de los mismos... o de las oficinas o por la llegada y salida de los trenes. (p. 18)

\footnotetext{
${ }^{1}$ García Niño, A. E. (julio-diciembre, 1992). Son como son...soneros. Glosas profanas para una crónica que se construye a sí misma en el tiempo. Eslabones. Revista semestral de Estudios Regionales, 4, 147-153.

${ }^{2}$ García Niño, A. E. (septiembre-noviembre, 2013). La narconarrativa: un subgénero literario fronterizo y binacional. Razón y Palabra, 18(84). Recuperado de http://www.razonypalabra.org.mx/N/N84/V84/14_Garcia_V84.pdf; García Niño, A. E. (2015). Don Winslow, autor de un clásico y otras obras dentro de la narconarrativa mexicano-estadounidense (una guía para forasteros). Álabe, 12. DOI: 10.15645/Alabe.2015.12.4

${ }^{3}$ García Niño, A. E. (enero-marzo, 2014). El cuarteto de la guerrilla de Carlos Montemayor o de cómo la imaginación de la realidad devino aporte historiográfico. Pacarina del Sur, 5(18). Recuperado de: www.pacarinadelsur.comindex.php?option=com_content\&view $=$ article\&id=886\&catid=4\&Itemid=2 ${ }^{4}$ García Niño, A. E. (julio-diciembre, 2014). ¡Strike one! Crónica del alborear de la Asociación Nacional de Beisbolistas y del crepúsculo del beisbol mexicano en 1980. Recorde. Revista de História do Esporte. Recuperado de: https://revistas.ufrj.br/index.php/Recorde/article/view/1564/1412
} 
Libro conformado por cinco partes y un anexo documental, en la inicial -la Presentación- García Niño expone de manera sucinta y sustentada en poco más de veinte páginas -11 a 32- sus motivos para la construcción del trabajo; traza un mapa de sitio en el cual inserta a Tierra Blanca como una ciudad ferrocarrilera importante por fuerza de su ubicación estratégica, y por ende relevante en el movimiento; pondera la dimensión de lo regional como aporte decisivo para que a partir de ahí el movimiento creciera hacia el resto del país y sobremanera hacia la capital mexicana; justifica el porqué de la historia oral para el caso y la reivindica como un recurso metodológico no sólo valedero, sino idóneo y nodal cuando se acude a documentar la historia de los anónimos.

Asimismo, en esa Presentación da a conocer algo digno de tomarse en cuenta: las tensiones del autor acerca de la manera en que se van definiendo sus decisiones ante las opciones que todo trabajo presenta, los cómo y porqué de incluir y/o desechar algo, los descubrimientos que la pesquisa misma le va ofreciendo tanto personal como académicamente, los recursos que la nostalgia aporta al conocimiento del pasado y lo anecdótico como herramienta narrativa. Y en esto que bien pudiéramos llamar las tripas del trabajo, y el resultado final, se manifiesta lo dicho por Ronald Fraser: ${ }^{5}$ la historia oral debe trascender la anécdota y la nostalgia, pero debe aprovechar a éstas como afluentes alimentadores que, sujetos a la crítica obligada de toda fuente informativa, pueden otorgarle el tono a lo contado.

La segunda parte cuenta, en voz de don Manuel García Amador, el proceso de gestación del llamado Plan Sureste, documento que sirvió como detonante y, al final, articulador de las demandas del movimiento en su integralidad y de la consiguiente democratización del sindicato: "se suscitó [el movimiento porque]... en enero del año anterior (1957) al firmar el nuevo contrato colectivo, que abarcaría [hasta el] 31 de diciembre de 1959, no se había otorgado ningún aumento salarial... porque nuestros dirigentes no lo habían demandado. ¿Puede alguien creer esto?” (pp. 34-35), cuenta el protagonista de los hechos. Y agrega que a partir de ahí se empezaron a mover los trabajadores del sureste, viajando hacia el centro, conjuntando demandas y consensuando lo que terminaría siendo el mencionado Plan luego de que la Gran Comisión Pro Aumento de Salarios, que había rebasado a la dirigencia sindical, acudió a la capital y obtuvo una negativa a todo. Fue así, dice don Manuel, que en los primeros días de

\footnotetext{
${ }^{5}$ Fraser, R. (1990). La formación de un entrevistador. Historia y fuente oral, 3, 129-150. Recuperado de: https://www.jstor.org/stable/27753274?seq=1\#page_scan_tab_contents
} 
mayo del 58 don Pancho Escalante, secretario general de nuestra sección sindical [la 25], informó en una asamblea ordinaria... del Plan y todos lo aprobamos. Se demandaban en él aumento de salarios y ganar de acuerdo al puesto y responsabilidad, así como un mejor trato para la gente e incluso cambios en los términos con los que se designaban a muchos de los trabajadores; por ejemplo: en el léxico del gobierno a los reparadores de vía se les llamaba peones, como si la Revolución no hubiera acontecido y siguiéramos en el Porfiriato.” (p. 36)

Sobrevendrían elecciones sindicales democráticas ganadas por el movimiento, los paros, las huelgas, los encarcelamiento de los dirigentes, la toma de las ciudades ferrocarrileras por parte del ejército, la alteración de la cotidianidad en ellas y la decidida participación de la ciudadanía que enriqueció y convirtió, por lo menos así fue en Tierra Blanca, un movimiento inicialmente laboral en uno social y civilista. Y todo esto en voz del protagonista adquiere, con el apoyo de la simbiosis entre el estilo "cuentero" del entrevistado y el oído para los giros coloquiales y la amigable prosa del entrevistador, un tono amable y cautivador de la atención que permite sin distracciones dar seguimiento a lo contado.

La tercera parte, también en viva voz de don Manuel García Amador, es una sintética historia de vida que ilustra, mediante algunas viñetas de ciertos hechos personales, familiares y laborales, los antecedentes que nos hacen comprensible al ser humano que llegó a ser un dirigente de la Sección 25 del Sindicato Nacional de Trabajadores Ferrocarrileros de la República Mexicana, cuya participación, como la del resto de los trabajadores, sus familias y sus vecinos terrablanquenses, fue incidente en el rumbo de los acontecimientos. Esta parte de la obra expone algo que por lo general se abstrae de las biografías de los líderes y dirigentes sociales en aras de darle relevancia a lo político público: el entramado del ámbito privado, e íntimo, desde donde emergen los actores para insertarse en la historia de lo social ampliado -local, regional, nacional- y terminar siendo sujetos sociales. La dimensión de lo humano elemental es entonces lo que alimenta la dimensión de lo cívico y de lo político público.

El cuarto apartado son las sintéticas conclusiones del autor y la terminal o estación final de, como dice García Niño, un viaje que le permitió entender a don Manuel

que la cotidianidad del movimiento fue un acto educativo puramente cívico... mostró que la resistencia civilista frente a la represión e invasión del espacio diario de vida es tarea y derecho de todos] en su papel de ciudadanos [y] en... lo familiar específico [le aportó] la 
certeza de que su actuar debería ser en pro de lo justo, convirtiéndose esto en una especie de guión de actuación vital. (p. 68)

No está de más señalar que el autor no duda en tomar partido sin dejar de ser crítico, como podrá percatarse quien se acerque al libro.

La quinta parte, aparentemente adyacente, es una muy útil cronología del movimiento que va de febrero de 1958 a abril de 1959: desde el reclamo de la Sección 15 del STFRM en el Distrito Federal por aumento salarial y los prolegómenos del Plan Sureste en mayo del mismo año, hasta la imposición gubernamental de Luis Gómez Z. como Secretario General del sindicato, después de la represión y el encarcelamiento de los dirigentes sindicales electos democráticamente. Muy útil, decía, porque pueden irse cotejando, a la par que se va leyendo el relato del protagonista, las vivencias y acciones desde la escala local/regional con la nacional y viceversa.

La bibliografía utilizada sirve no sólo para apuntalar lo dicho por quién testimonia su vida y su acción sindical y política, sino para estructurar el tiempo y espacio que hicieron posible tanto la emergencia y crecimiento del movimiento ferrocarrilero como su némesis represiva gubernamental. Es también una instantánea del precario estado del arte en torno a uno de los dos o tres movimientos laborales y sociales mexicanos más importantes de la segunda parte del siglo recientemente concluido.

$\mathrm{El}$ anexo documental, textos e imágenes, abunda per se en el tópico y apuntala, unido al ya enunciado aparato crítico, lo dicho por Anthony Grafton: ${ }^{6}$ el corpus de un texto puede o no convencer, pero ineludiblemente las notas a pie y sus contenidos documentales demuestran. Y el anexo lo hace.

No hay texto historiográfico perfecto, por supuesto. Hay sí obras mejores o peores, justas e injustas, más o menos certeras. Y Convertimos la lucha en patrimonio... es, además de un trabajo didáctico tanto por el continente como por el contenido y su agradecible extensión -poco más de cien páginas-, una sincera aproximación que visibiliza un tópico ciertamente excéntrico en la historiografía mexicana desde el ámbito de lo regional, y esto es ya de suyo meritorio; al igual que lo es apostar por la historia oral y argumentar con sinceridad el porqué de la apuesta. Quizás el autor lo decidió así por estar convencido de su buen oído y su oficio para recuperar el habla del protagonista, así como su capacidad para trasladar a la grafía la fonética y las circunstancias expresivas

${ }^{6}$ Grafton, A. (1998). Los orígenes trágicos de la erudición. México: FCE. 
personales del entrevistado, lo que recuerda, guardando las obvias distancias, a Ricardo Garibay y Las glorias del gran Púas, por ejemplo. Pero también recuerda una obra reciente y poco comentada, coordinada por Necoechea Gracia y Pensado Leglise, ${ }^{8}$ que incide tanto en lo teórico como en lo práctico de la historia oral a través de ejemplares textos y demuestra la buena salud de que goza ella entre nosotros.

Convertimos la lucha en patrimonio... se adscribe dignamente a esa vertiente de las historias con minúsculas y excéntricas que buscan dar voz a los habitantes de la anonimia. Y bien merecía una edición menos austera que la aquí comentada, la cual pudiera haberle otorgado un mayor protagonismo al anexo documental que define por escrito y visualmente la vida de don Manuel García Amador, uno de esos tantos anónimos que han hecho, hacen y le dan sentido a la Historia con mayúsculas.

Leticia Núñez Hernández Universidad Veracruzana, México letticianunez@hotmail.com

\footnotetext{
${ }^{7}$ Garibay, R. (1978). Las glorias del gran Púas. México: Grijalbo.

${ }^{8}$ Necoechea Gracia, G. y Pensado Leglise, P. (coords.). (2013). El siglo XX que deseábamos. Ensayos de historia oral en torno a experiencia y expectativa. México: INAH.
} 